\title{
Alleviation of High Temperature Stress in Strawberry Plants Infected with Arbuscular Mycorrhizal Fungi
}

\author{
Yoh-ichi Matsubara, Itsuka Hirano, Daisuke Sassa and Kaneyuki KoshiKawa* \\ Faculty of Agriculture, Gifu University, Gifu 501-1193, Japan \\ * Gifu Prefectural Research Institute for Agricultural Sciences, Gifu 501-1152, Japan
}

(Received August 4, 2003)

\begin{abstract}
Alleviation of high temperature stress in strawberry (Fragaria $\times$ ananassa, Duch., cv. Nohime) plants infected with arbuscular mycorrhizal (AM) fungi (Gigaspora margarita, Glomus fasciculatum, Gl. mosseae, Gl. sp. R10, Gl. aggregatum) was observed. During the raising seedling in hot season (July and August in 2002), temperatures in both the greenhouse and soil in the pot fluctuated similarly, and the daily maximum temperature reached over $35^{\circ} \mathrm{C}$ almost every day. Ten weeks after inoculation, incidence and severity of browning in leaves became lower in AM plants than in non-AM (NAM) ones. Root browning occurred in all plots, however, AM plants had lower severity than NAM ones, especially in Gl. mosseae and Gl. aggregatum plots. AM plants gave greater values in the following parameters : no. of leaves and roots, leaf area, diameter of crown and dry weight of leaves and roots than those in NAM ones; Gl. aggregatum plot showed relatively higher dry weight of leaves and roots than the other species. No characteristic relationship occurred between AM fungal infection level or phosphorus content in plants and alleviation of high temperature stress. These findings suggest that high temperature stress was alleviated in AM fungus-infected strawberry plants and the effect differed with fungal species.
\end{abstract}

Keywords : arbuscular mycorrhizal fungi, high temperature stress, strawberry, symbiosis

\section{INTRODUCTION}

In strawberry cultivation, high temperature during nursery production often restricts root growth and induces browning of roots and petioles resulting in withering and causing great losses of plants, especially in the warm climate regions in Japan. However, characteristics of high temperature tolerance in strawberry plants remain unclear, and recently, the evaluation methods of high temperature tolerance in strawberry plants have been investigated (Tsukiji et al, 2002).

Arbuscular mycorrhizal (AM) fungi have the effect of promoting host plant growth mainly by enhancing phosphorus uptake through symbiosis (Marschner and Dell, 1994). As for strawberry plants, growth enhancement through AM fungus inoculation was reported in several combinations of AM fungal species and strawberry cultivars (Robertson et al., 1988; Chavez and Ferrera, 1990; Niemi and Vestberg, 1992; Williams et al., 1992; Varma and Schuepp, 1994). Schenck and Smith (1982) and Haugen and Smith (1992) also reported that AM fungus-infected plants produced more dry weight of shoots and roots than non-inoculated

Corresponding author: Yoh-ichi Matsubara, fax : +81-58-293-2887, e-mail : ymatsu@cc.gifu-u.ac.jp 
ones under high soil temperature in soybean and mung bean, respectively. On the other hand, Matsubara et al. (2000) reported that high and low temperature stress tolerance occurred in asparagus plants infected with AM fungi, and supposed that temperature stress tolerance might be induced by AM fungal infection. However, it has been unclear that the response to high temperature stress in AM fungus-infected strawberry plants and the response depends on AM fungal species.

In this study, effect of high temperature stress on the raising of strawberry plants infected with $\mathrm{AM}$ fungi was investigated using five AM fungal species.

\section{MATERIALS AND METHODS}

Inoculation of AM fungus. Strawberry (Fragaria $\times$ ananassa, Duch., cv. Nohime) plants were obtained by directly rooted runners from mother plants. Bedding soil, coconut-

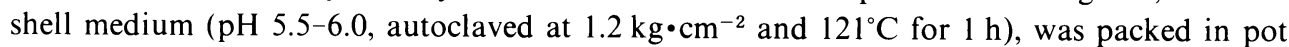
$(10.5 \mathrm{~cm}$ in diameter) and strawberry runner plants were inoculated with arbuscular mycorrhizal (AM) fungi (Gigaspora margarita, Glomus fasciculatum, Gl. mosseae, Gl. sp. R10, Gl. aggregatum), according to Matsubara and Harada (1996a), using commercial inocula at late of June in 2002. Four weeks after AM fungus inoculation at late of July in 2002, runners were cut from the mother plants, and the AM fungus-inoculated plants (AM plants) and noninoculated control plants (NAM plants) were administered a mixed fertilizer ( $N: P: K=13$ : $11: 13,1 \mathrm{~g}$ per pot). Six plots, consisting of fifteen plants per plot with no replication, were irrigated by a capillary watering method as regularly and raised in a greenhouse at Gifu Prefecture Research Institute.

Evaluation of AM fungal infection level. Ten weeks after AM fungus inoculation, roots were sampled and stained according to Phillips and Hayman (1970) and the ratio of AM fungal infections in $1-\mathrm{cm}$ segments of lateral roots (RFISL) was calculated. Hence, RFISL expresses the percentage of $1-\mathrm{cm}$ AM fungus-infected segments in approx. 50 samples of 1-cm segments of lateral roots per plant. The average was calculated from the values of three plants.

Estimation of browning in leaves and roots. Ten weeks after AM fungus inoculation, the browning symptoms in leaves and roots of ten plants per plot were categorized into 4 degrees: 0 , no browned; 1 , a part browned; 2, half browned; 3 , all browned. The index of browning was calculated by the following formula :

$$
\text { Index of browning }=\frac{\sum \text { (number of plants } \times \text { degree of browning) }}{\text { Total number of plants } \times 3} \times 100
$$

Determination of phosphorus in plants. The content of phosphorus $(\mathrm{P})$ in plants was measured at 10 weeks after inoculation. Leaves and roots from 5 plants were sampled and dry matter was weighed after drying at $110^{\circ} \mathrm{C}$ for 2 days. The samples were ground, wet-ashed, and their P contents was determined, according to Matsubara and Harada (1996a).

\section{RESULTS}

During the raising seedling after runner cutting, temperatures in both the greenhouse and soil in the pot fluctuated similarly (Fig. 1). The daily maximum temperature reached over $35^{\circ} \mathrm{C}$ almost every day. Ten weeks after inoculation, incidence and severity of browning in leaves became lower in AM plants than in NAM ones (Fig. 2). In NAM plants, the incidence in leaves reached $100 \%$ and all plants showed maximum degree of the symptom, while in AM ones, most of the plants showed minimum degree of the symptom. Root browning occurred in all plots and AM plants had lower severity than NAM ones, especially in Gm and Ga plots. 


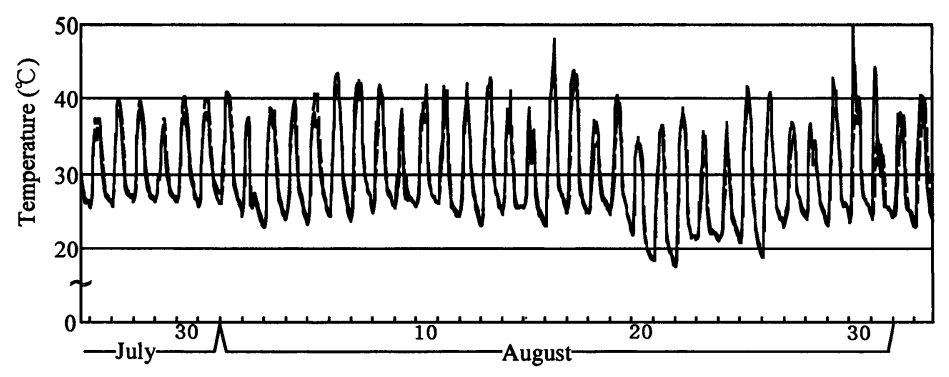

Fig. 1 Diurnal changes in air temperature (-) in the greenhouse and soil temperature (-..-) in the pot.

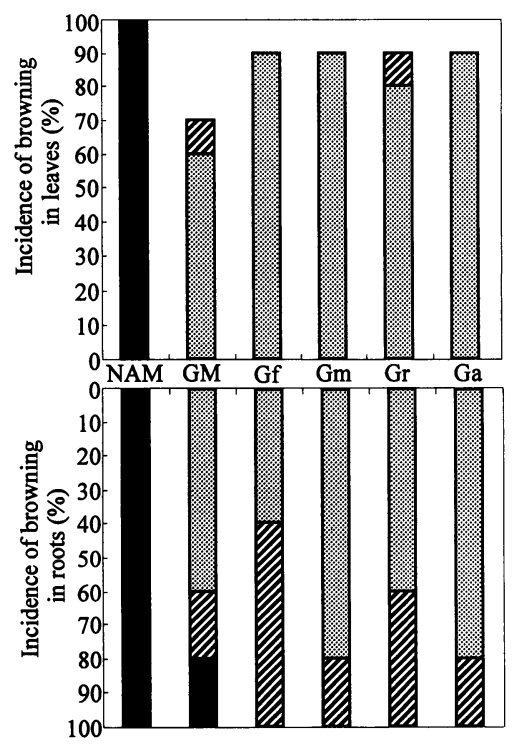

Fig. 2 Incidence of browning in leaves and roots of strawberry plants at 10 weeks after AM fungus inoculation. NAM, AM fungusnon-inoculated; GM, Gigaspora margarita; Gf, Glomus fasciculatum; Gm, Glomus mosseae; Gr, Glomus sp. R10; $\mathrm{Ga}$, Glomus aggregatum $(\mathrm{n}=10)$. N, a part browned; $\mathbb{Z}$, half browned; $\mathbf{Q}$, all browned.

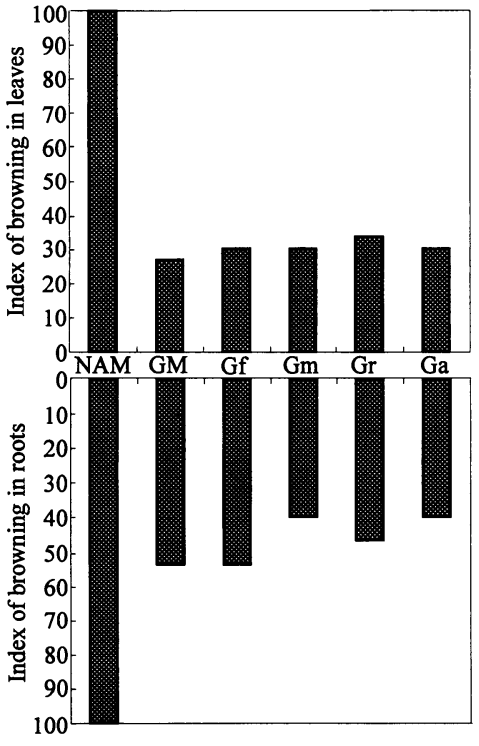

Fig. 3 Index of browning in leaves and roots of strawberry plants at 10 weeks after AM fungus inoculation. 0 , healthy; 100 , all leaves or roots were browned. NAM, GM, Gf, Gm, Gr, Ga, see Fig. $2(\mathrm{n}=10)$.

Indices of browning in leaves and roots became lower in AM plants than in NAM ones; no obvious difference appeared in the indices among AM fungal species (Fig. 3). Ten weeks after inoculation, AM plants gave greater values in the following parameters : no. of leaves and roots, leaf area, diameter of crown and dry weight of leaves and roots than those in NAM ones; Ga showed higher dry weight of roots than the other species (Figs. 4-7). RFISL differed with fungal species, GM and Gf became higher than the other species; Gr was lowest among the species (Fig. 8). P content in leaves and roots were lower in almost of the AM plants than in NAM ones (Fig. 9). 


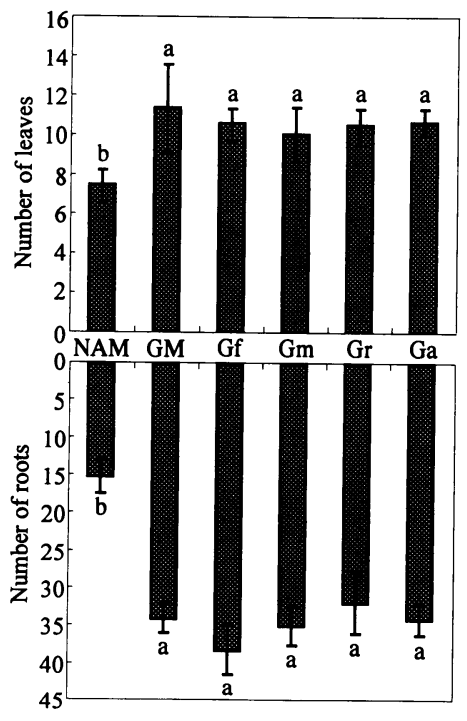

Fig. 4 Effect of AM fungus inoculation on the number of leaves and roots in strawberry plants at 10 weeks after AM fungus inoculation. NAM, GM, Gf, Gm, Gr, Ga, see Fig. 2. Bars represent standard errors $(n=10)$. Means with different letters are significantly different at $5 \%$ level by LSD.

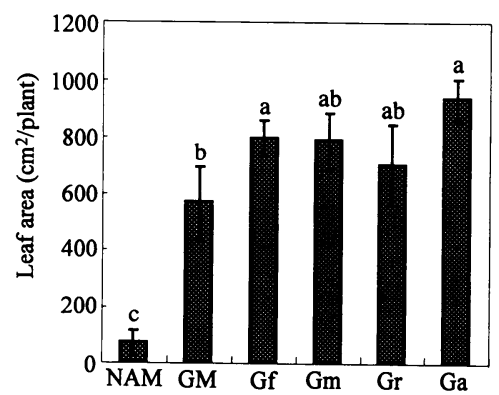

Fig. 5 Influence of AM fungus inoculation on leaf area in strawberry plants at 10 weeks after AM fungus inoculation. NAM, GM, Gf, $\mathrm{Gm}, \mathrm{Gr}, \mathrm{Ga}$, see Fig. 2. Bars represent standard errors $(n=10)$. Means with different letters are significantly different at $5 \%$ level by LSD.

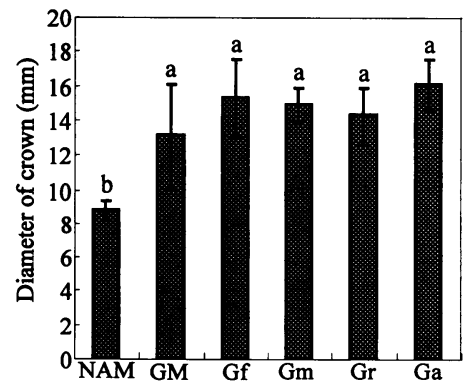

Fig. 6 Influence of AM fungus inoculation on diameter of crowns in strawberry plants at 10 weeks after $\mathrm{AM}$ fungus inoculation. NAM, GM, Gf, Gm, Gr, Ga, see Fig. 2. Bars represent standard errors $(n=10)$. Means with different letters are significantly different at $5 \%$ level by LSD.

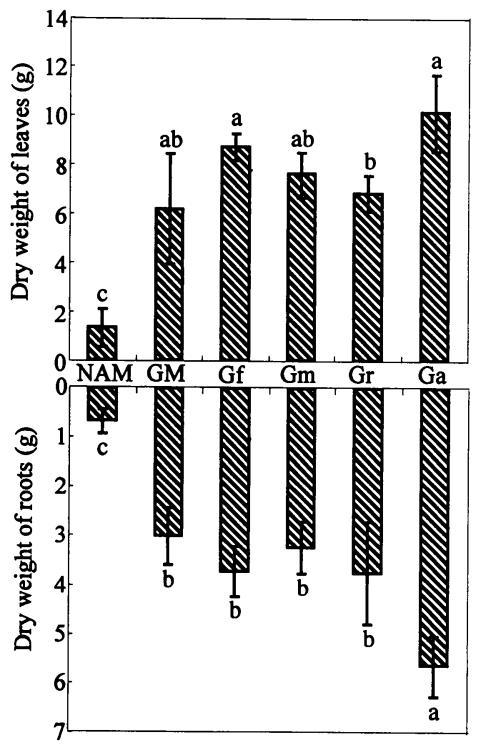

Fig. 7 Dry weight of strawberry plants at 10 weeks after AM fungus inoculation. NAM, GM, Gf, Gm, Gr, Ga, see Fig. 2. Bars represent standard errors $(n=10)$. Means with different letters are significantly different at $5 \%$ level by LSD.

\section{DISCUSSION}

In the present study, growth promotion through AM fungal symbiosis appeared in strawberry plants, and both incidence and severity of browning of leaves and roots, mainly caused by successive stress of high temperature for roots, were reduced by pre-infection with AM fungi. These findings indicate that high temperature stress was alleviated by AM fungal 


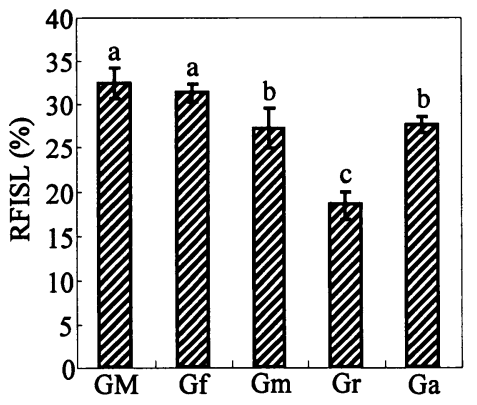

Fig. 8 Ratio of AM fungus-infected segments in lateral roots (RFISL) at 10 weeks after AM fungus inoculation. GM, Gf, Gm, Gr, Ga, see Fig. 2. Bars represent standard errors $(n=3)$. Means with different letters are significantly different at $5 \%$ level by LSD.

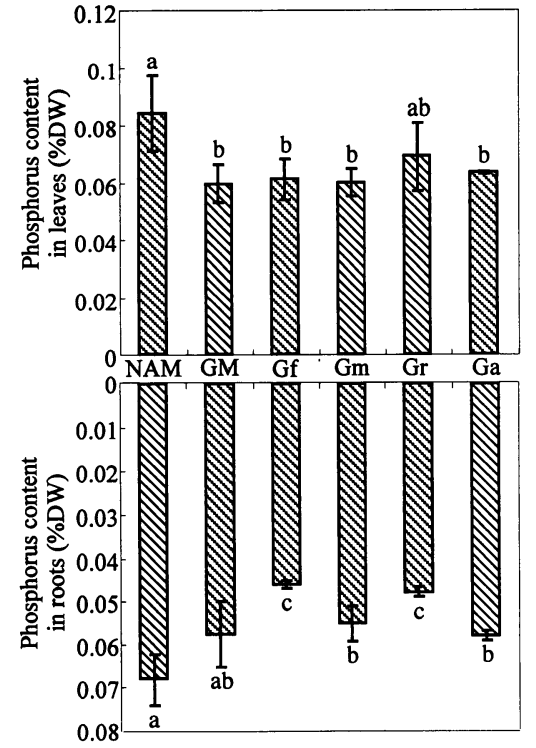

Fig. 9 Phosphorus content in strawberry plants at 10 weeks after $A M$ fungus inoculation. NAM, GM, Gf, Gm, Gr, Ga, see Fig. 2. Bars represent standard errors $(n=5)$. Means with different letters are significantly different at $5 \%$ level by LSD.

infection. However, the effect differed with the AM fungal species in which Gm and Ga were relatively most effective. Schenck and Smith (1982) reported that AM fungus-infected plants produced more dry weight of shoots and roots than non-inoculated ones under high soil temperature in soybean, and the effect differed with fungal species. Shrestha et al. (1995) demonstrated that satsuma mandarin trees infected with AM fungus showed greater growth and photosynthetic activity compared with non-inoculated ones under high temperature in August, though the effect differed with fungal species. Matsubara et al. (2000) reported that the temperature stress tolerance differed with the AM fungal species in asparagus plants. Our data support their findings, however, in this study, we could not clarify the difference in the response to high temperature among AM fungal species. Schenck and Smith (1982) reported that AM fungal infection level was not associated with the growth response to high soil temperature in soybean. In our study, no clear relationship between AM fungal infection level and the response to high temperature was observed. Sutton (1973) demonstrated that the AM fungal infection consisted of three phases: (1) a lag phase during which spore germination, germ tube growth, and initial penetration occur, (2) a rapid growth phase, coinciding with the development of external mycelium, and spread of the fungus within the roots and (3) a stable phase during which the proportion of infected roots to non-infected ones remains nearly constant. In this study, the RFISL was investigated only 10 weeks after inoculation, so that it is difficult to estimate the RFISL showed the maximum values in each fungal species and estimate the relationship between the response to high temperature and RFISL. As for the relationship between $\mathrm{P}$ content and alleviation of high temperature stress, our data show that there is no clear difference in $\mathrm{P}$ content among AM plants, which indicates that $\mathrm{P}$ content in plants has little influence on the response to high temperature in AM fungus-infected plants. In this study, P content decreased in most of the AM plants compared with NAM ones, 
supposing that intensive consumption in $\mathbf{P}$ for growth promotion might occur in AM plants, which caused to decrease in P. On the other hand, Marschner and Dell (1994) reported that uptake of mineral nutrient except $P$ was also promoted in AM fungus-infected plants. Thus, some other factors caused by AM fungal infection might be related to the alleviation of high temperature stress.

Matsubara and Harada (1996b) reported that the optimum temperatures for both spore germination and hyphal growth of AM fungus differred between Gigaspora margarita and Glomus etunicatum. Schenck et al. (1975) reported that the optimum temperatures for spore germination are $20^{\circ} \mathrm{C}-25^{\circ} \mathrm{C}$ for Glomus mosseae, and $34^{\circ} \mathrm{C}$ for both Gigaspora coralloidea and Gigaspora heterogama. Thus, the optimum temperature for fungal growth differs among the species, so that the difference in response to high temperature stress among the fungi in this study might be partially associated with each fungal characteristic for temperature. Further investigations would be needed on this point.

Our results reveal that the symbiotic relationship provides vigorous leaf and root growth under uncertainly fluctuating temperatures, resulting in fast growing, vigorous plants with a high yield potential, and that the selection of appropriate combinations with a high affinity between host and fungus species which tolerate temperature stress is important.

\section{REFERENCES}

Chavez, M. G., Ferrera, R. C. 1990. Effect of vesicular arbuscular mycorrhizae on tissue culture-derived plantlets of strawberry. HortScience 25 : 903-905.

Haugen, L. M., Smith, S. E. 1992. The effect of high temperature and fallow period on infection of mung bean and cashew roots by the vesicular-arbuscular mycorrhizal fungus Glomus intraradices. Plant Soil 145 : $71-80$.

Marschner, H., Dell, B. 1994. Nutrient uptake in mycorrhizal symbiosis. Plant Soil 159 : 89-102.

Matsubara, Y., Harada, T. 1996a. Effect of arbuscular mycorrhizal fungus infection on growth and mineral nutrient content of Asparagus officinalis L. seedlings. (Japanese text with English summary) J. Jpn. Soc. Hortic. Sci. 65 : 303-309.

Matsubara, Y., Harada, T. 1996b. Effect of constant and diurnally fluctuating temperatures on arbuscular mycorrhizal fungus infection and the growth of infected asparagus (Asparagus officinalis L.) seedlings. J. Jpn. Soc. Hortic. Sci. 65 : 565-570.

Matsubara, Y., Kayukawa, Y., Fukui, H. 2000. Temperature-stress tolerance of asparagus seedlings through symbiosis with arbuscular mycorrhizal fungus. J. Jpn. Soc. Hortic. Sci. 69: 570-575.

Niemi, M., Vestberg, M. 1992. Inoculation of commercially grown strawberry with VA mycorrhizal fungi. Plant Soil 144 : 133-142.

Phillips, J. M., Hayman, D. S. 1970. Improved procedures for clearing roots and staining parasitic and vesicular-arbuscular mycorrhizal fungi for rapid assessment of infection. Trans. Br. Mycol. Soc. 55 : 158-163.

Robertson, W. J., Boyle, C. D., Brown, H. L. 1988. Endomycorrhizal status of certified strawberry nursery stock. J. Am. Soc. Hortic. Sci. 113 : 525-529.

Schenck, N. C., Graham, S. O., Green, N. E. 1975. Temperature and light effect on contamination and spore germination of vesicular-arbuscular mycorrhizal fungi. Mycologia 67 : 1189-1192.

Schenck, N. C., Smith, G. S. 1982. Responses of six species of vesicular-arbuscular mycorrhizal fungi and their effects on soybean at four soil temperatures. New Phytol. 92 : 193-201.

Shrestha, Y. H., Ishii, T., Kadoya, K. 1995. Effect of vesicular-arbuscular mycorrhizal fungi on the growth, photosynthesis, transpiration and the distribution of photosynthates of bearing satsuma mandarin trees. J. Jpn. Soc. Hortic. Sci. 64 : 517-525.

Sutton, J. C. 1973. Development of vesicular-arbuscular mycorrhizae in crop plants. Can. J. Bot. 51 : 2487-2493.

Tsukiji, K., Imada, S., Dan, K. 2002. Evaluation of high temperature acclimation in strawberry by leaf 
discs thermostability. (Japanese text) J. Jpn. Soc. Hortic. Sci. 71 (suppl. 2) : 373.

Varma, A., Schuepp, H. 1994. Infectivity and effectiveness of Glomus intraradices on micropropagated plants. Mycorrhiza 5 : 29-37.

Williams, S. C. K., Vestberg, M., Uosukainen, M., Dodd, J. C., Jeffries, P. 1992. Effects of fertilizers and arbuscular mycorrhizal fungi on the post-vitro growth of micropropagated strawberry. Agronomie 12 : $851-857$.

\section{〈和文抄録〉}

\section{Arbuscular 菌根菌が感染したイチゴ苗における高温ストレス障害の軽隇}

\section{松原陽一・平野生華・佐々大輔・越川兼行*}

岐阜大学農学部・*岐阜県農業技術研究所

イチゴ (Fragaria $\times$ ananassa, Duch., cv. 濃姫)のランナーに arbuscular 菌根菌 5 菌種 (Gigaspora margarita, Glomus fasciculatum, Gl. mosseae, Gl.sp. R10, Gl. aggregatum) を接種し, 夏季育苗に おいて発生する高温ストレス障害への耐性評価を行った. 夏季育苗期（2002 年 7〜8 月）における 温室内気温および育苗培地温度はほぼ同様に変動し，日中の最高気温が $35^{\circ} \mathrm{C}$ 越える日が多かつ た。菌根菌接種 10 週間後, 高温ストレスによる葉および根における褐変症状の発生率並びに発生 程度は接種区で無接種区より軽減し, その効果には菌種間差がみられた. 特に軽減効果が高かった のは Gl. mosseae 区および Gl. aggregatum 区であった。一方，菌根菌接種個体では菌種にかかわ らず, 葉数, 葉面積, クラウン径, 根数, 葉掞よび根の乾物重が無接種個体を上回った. 菌根菌感 染率および植物体りン酸含量と高温ストレス障害の軽減効果との間に一貫した関連性はみられな かった。 